\title{
Sonication of Activated Sludge Flocs and the Recovery of their Bacteria on Solid Media
}

\author{
By C. J. BANKS AND I. WALKER \\ Department of Biology, University of York, Heslington, York YO I ${ }_{5} D D$
}

(Received 9 June 1976)

\begin{abstract}
SUMMARY
To enumerate the bacteria present in activated sludge it is necessary to release them undamaged from the flocs. Samples of diluted activated sludge were sonicated for periods ranging from 20 to $240 \mathrm{~s}$ at five different intensities. During sonication, floc disruption was followed by measuring the absorbance of treated samples at 400 and $610 \mathrm{~nm}$, energy input by recording changes in temperature and the release of viable organisms by plating techniques.

The release of bacteria depended on the intensity and duration of sonication. Most viable bacteria were recovered after 80 to Ioo s at a power output of $26 \mathrm{~J} \mathrm{~s}^{-1}$. Patterns of recovery of viable bacteria from Io different activated sludges were of two types. Comparable recovery of bacteria from identical samples showed that two instruments could be successfully compared using physical criteria only.

After sonication the number of bacteria recovered depended on the isolation medium. More bacteria were recovered from Casitone glycerol yeast extract agar than from Tryptone glucose beef and yeast extract vitamins agar (TGEVA) for five out of six sludges, and more were recovered from minimal pyruvate than from TGEVA for three out of six sludges.
\end{abstract}

\section{INTRODUCTION}

The activated sludge process for the treatment of water-borne wastes relies on an acclimatized bacterial population quickly absorbing and oxidizing the pollutants. This is achieved by flocculated organisms in the secondary settlement tank being recycled as an 'active' biomass for treatment of further waste. The flocs consist of individual bacteria in a matrix of polymeric material.

The study of types and numbers of organisms present is necessary for a fuller understanding of the biological process. Agar plating methods require a uniform liquid dispersion, and so the bacterial floc must first be broken up to yield individual organisms. Williams et al. (1970) and Williams, Forster \& Hughes (197I) used a device which generated acoustic microstreaming around a submerged oscillating wire. This produced hydrodynamic shear forces sufficiently strong to disrupt sludge flocs, without causing death of the microbes. Viable counts were increased and were consistent with theoretical predictions. Particle size analysis, using a Coulter counter and electron micrographs, gave evidence supporting floc disruption after ultrasonic treatment. Pike, Carrington \& Ashburner (I97I) compared several homogenization techniques for breaking bacterial flocs from activated sludge and proposed a method for routine counting of viable organisms, disrupting the flocs in a Kerry ultrasonic cleaning bath.

No single medium will support the growth of all nutritional types of heterotrophic bacteria present in activated sludge (Prakasam \& Dondero, I967a, $b$; Lighthart \& Oglesby, I969; 
Unz \& Davis, 1975). Comparative studies have shown that different media offer advantages for the recovery of different organisms. Pike et al. (1972) found Casitone glucose yeast extract agar (CGY) gave the highest median counts for the enumeration of bacteria from activated sludge. They also showed that approximately $17 \%$ fewer organisms are recovered on nutrient agar, as used by Allen (1944), than on CGY. Lighthart \& Oglesby (1969) considered that Tryptone glucose extracts and vitamins agar (TGEVA) was best for the general cultivation of activated sludge bacteria.

Our aim was to determine the optimal conditions for recovery of viable organisms from flocs obtained from sludges grown under different nutritional and hydraulic conditions. This is necessary to assess the characteristics of viable organisms in relation to their activity (Banks et al., 1976). Absorbance measurements were used to assess the degree of floc breakage and, therefore, total number of cells released; dilution plates were used to count viable bacteria.

\section{METHODS}

Sonication. Samples of mixed liquor from the aeration tanks of activated sludge plants were diluted $\mathrm{I}$ in ro with buffer ( $5 \mathrm{mg}$ penta-sodium triphosphate $1^{-1}$ ) to give a sample volume of 50 or $100 \mathrm{ml}$. Two soniprobes (models I 130 and 7532A, Dawe Instruments, London $\mathrm{W}_{3} \mathrm{OSD}$ ) fitted with $25 \mathrm{~mm}$ diam. tips were used at different power output levels. When the samples were to be cultured, sonication was carried out in a $125 \mathrm{ml}$ vessel cooled by circulating iced water. The temperature was measured with a Comark electronic thermometer fitted with a $\mathrm{Cu} /$ constantan thermocouple.

Physical measurement of floc breakage. During sonication, $2 \mathrm{ml}$ portions of the sample were removed and mixed with $2 \mathrm{ml}$ polyphosphate buffer. After allowing 10 min for settling at room temperature, the top $2 \mathrm{ml}$ of the mixture was carefully removed and its absorbance was measured at 400 and $610 \mathrm{~nm}$ with a Bausch and Lomb Spectronic 20.

Media. CGY agar (Pike et al., 1972) was used except where otherwise stated. It contained ( $\mathrm{g}^{-1}$ ): Casitone, 5; glycerol, 5; yeast extract, I ; and agar (Oxoid no. 3 ), I3; $\mathrm{pH} \mathrm{7 \cdot 2.} \mathrm{Other}$ media used were TGEVA (Lighthart \& Oglesby, 1969) and a minimal pyruvate medium

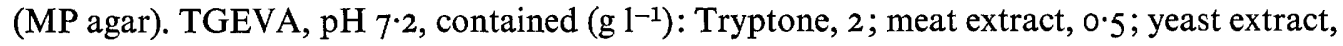
0.4 ; glucose, I; and agar (Difco Bacto), 15 . The medium was supplemented after sterilization with a u.v.-sterilized vitamin solution to give final concentrations in the medium of $\left(\mu \mathrm{g}^{-1}\right)$ : $\mathrm{Br}$, I00; biotin, 500; thiamin, 500; niacinamide, 500; calcium pantothenate, 100; and riboflavin, 500. MP agar, $\mathrm{pH} 7 \cdot 0$, contained $\left(\mathrm{g} \mathrm{l}^{-1}\right)$ : sodium pyruvate, $3 ;\left(\mathrm{NH}_{4}\right)_{2} \mathrm{SO}_{4}$, I ; $\mathrm{KH}_{2} \mathrm{PO}_{4}, 0.276 ; \mathrm{K}_{2} \mathrm{HPO}_{4}, 0.533$; agar (Difco Bacto), $\mathrm{I} 5$; and $0 . \mathrm{I} \mathrm{ml}$ mineral salt mixture (Meynell \& Meynell, I965). Sodium pyruvate was sterilized by filtration of a $\mathrm{I} \cdot 5 \% \mathrm{w} / \mathrm{v})$ solution in $200 \mathrm{ml}$ double-distilled water.

All media constituents were sterilized, except where otherwise stated, by autoclaving at $12 \mathrm{I}{ }^{\circ} \mathrm{C}$ for $15 \mathrm{~min}$.

Culture technique. Portions ( $\mathrm{I} \mathrm{ml}$ ) were removed from the sonication vessel at intervals and serially diluted in polyphosphate buffer. Duplicate $0.1 \mathrm{ml}$ samples from the dilution tubes were spread on the appropriate agar and plates were incubated for 7 days at $20{ }^{\circ} \mathrm{C}$ before counting the colonies. The time between taking the initial sample and the final plating never exceeded $30 \mathrm{~min}$. 

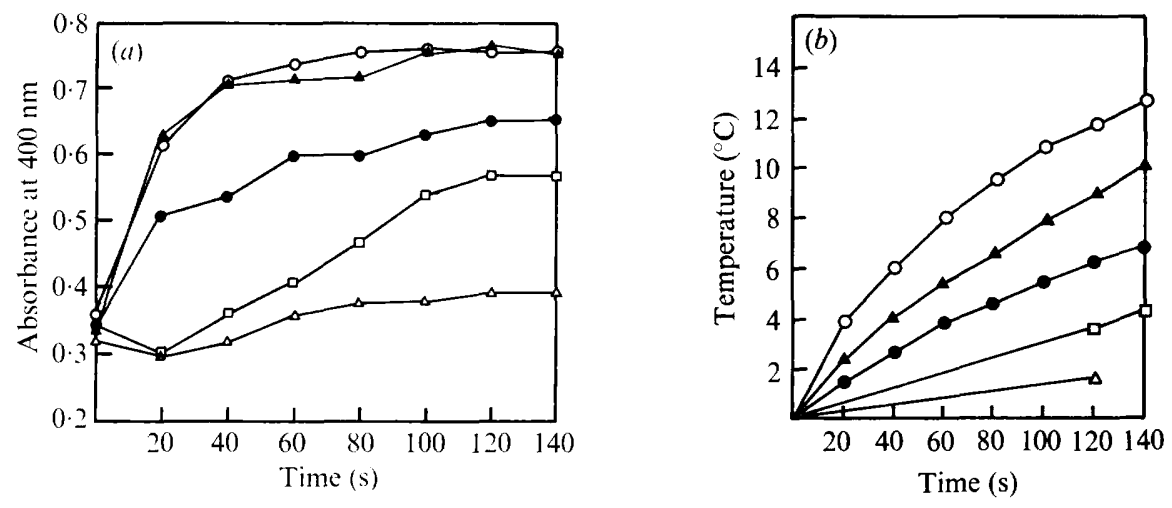

Fig. I. Effects of intensity of sonication on $(a)$ absorbance, $(b)$ temperature of sample. Power output levels correspond to scale readings $I \cdot 2(\triangle) ; 1.8(\square) ; 2.6(\bullet) ; 3.6(\Lambda) ; 4.9(O)$.
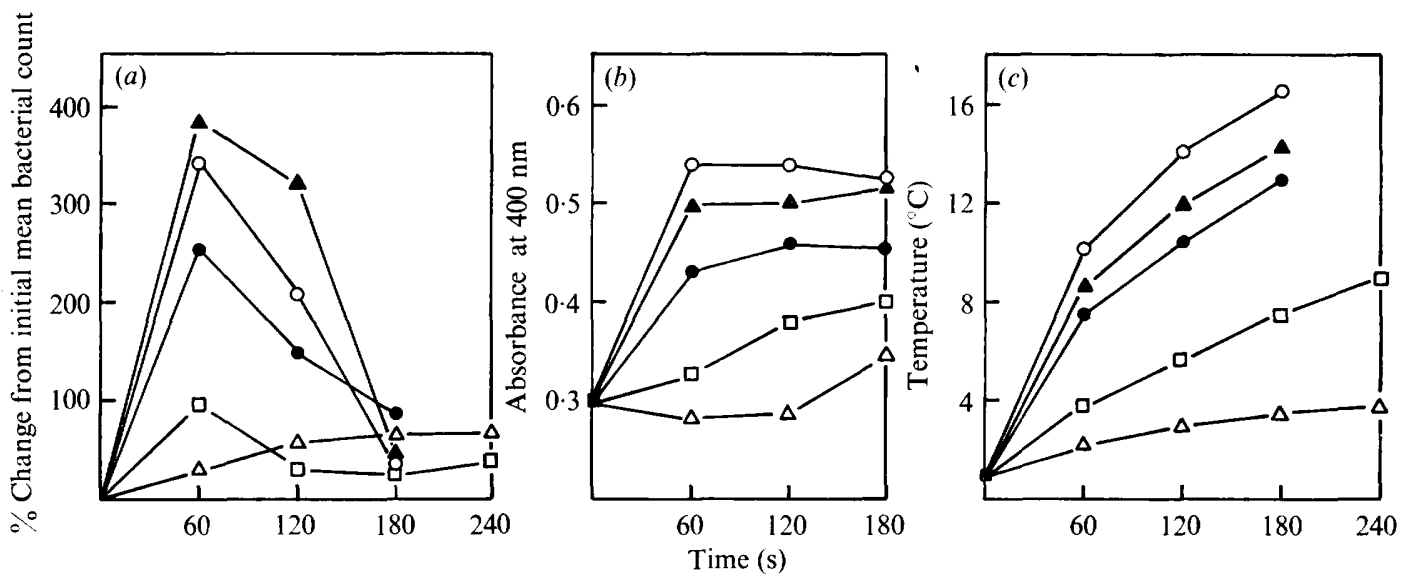

Fig. 2. Effects of intensity of sonication on (a) the bacterial count, and on sample characteristics (b) absorbance and $(c)$ temperature. Power outputs correspond to scale readings $I \cdot 2(\triangle) ; I \cdot 8(\square)$; $2.6(\odot) ; 3.6(\Delta) ; 4.9(\bigcirc)$.

\section{RESULTS AND DISCUSSION}

Floc breakage

The effects of duration and intensity of sonication on the absorbance of supernatants are shown in Fig. I (a). The absorbance of the 'bacterial fraction', broken from the flocs and remaining in suspension in the buffer, reached a maximum' after $100 \mathrm{~s}$ sonication. The amount 'of this fraction and its initial rate of formation were related to the power output and the sample size and solids concentration. At low power output levels (scale readings $\mathrm{I} \cdot 2$ and $\mathrm{I} \cdot 8$ ) there was a small decrease in absorbance; this may have been caused by the mixing, which occurs during mild sonication, allowing the coalescence of floc units to form quicker settling floc aggregates (Kiff, I975).

The fact that floc breakage depended on the intensity rather than the duration of sonic input suggests that flocs can be characterized by their binding energies. All the binding energy must be overcome for complete disruption to occur. Differential sonication experiments, with measurements of temperature, may prove useful in assessing floc strength.

To assess the heating effect of prolonged sonication, the temperature in the sonicating 


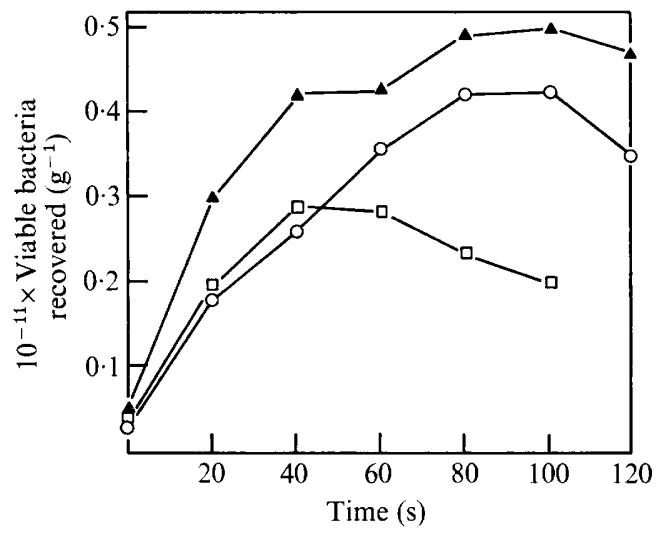

Fig. 3

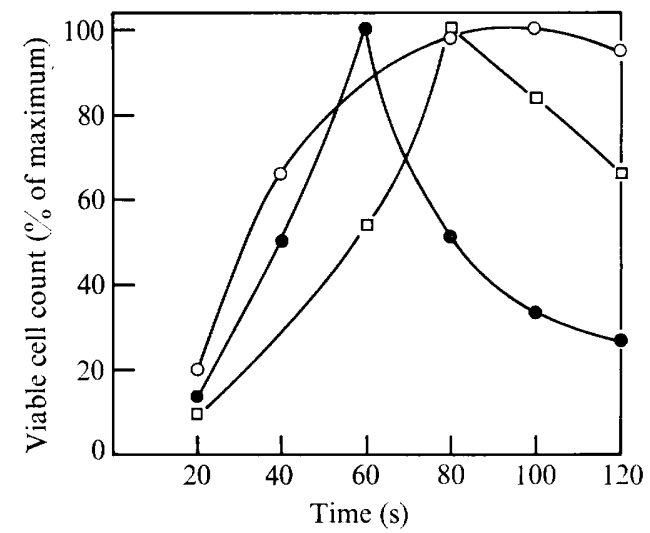

Fig. 4

Fig. 3. The release of viable bacteria from diluted mixed liquor. The sample was obtained from a laboratory-scale activated sludge plant operating at a solids concentration of $\mathrm{I}^{\cdot} 9 \mathrm{~g} \mathrm{l}^{-1}$, and numbers of viable bacteria are expressed per $\mathrm{g}$ dry wt sludge. Power outputs correspond to scale readings $2.4(\square) ; 3.6(\Delta) ; 5.0(\bigcirc)$.

Fig. 4. Examples showing the recovery of viable organisms as a function of the period of sonication. The samples were obtained from three municipal treatment works.

vessel was measured at $20 \mathrm{~s}$ intervals for different power output levels (Fig. I $b$ ). The temperature increased from o to $13{ }^{\circ} \mathrm{C}$ over $\mathrm{I} 40 \mathrm{~s}$ at maximum power output. This suggests that heating lethal to bacteria is unlikely to be encountered under the conditions used.

At a power setting corresponding to scale reading $3 \cdot 6$ (subsequently shown to be optimum for the recovery of bacteria), the power output of the model II 30 probe was $26 \mathrm{~J} \mathrm{~s}^{-1}$ as estimated from the temperature data corrected for heat loss due to cooling.

\section{Recovery of organisms}

Samples were removed at I min intervals during sonication at various power outputs to determine the effect of sonication on the release of viable organisms from flocs. Figure $2(a)$ shows the percentage increase in the numbers of bacteria recovered over those from unsonicated controls; Figs $2(b)$ and $(c)$ show the corresponding physical data. At the lowest power output (scale reading $\mathrm{I} \cdot 2$ ), the numbers of bacteria recovered reached a plateau after 2 min sonication. At higher power outputs maximum recovery was attained after $60 \mathrm{~s}$; after this time the numbers of viable bacteria rapidly declined. At the maximum power setting (scale reading $4 \cdot 9$ ) less viable bacteria, were recovered probably due to increased lethal effects of sonication. The power output level with a scale reading of 3.6 allowed maximum recovery of viable cells.

To improve the resolution of the peaks in Fig. $2(a)$, the experiment was repeated on a different sludge using shorter intervals between sampling. The numbers of organisms recovered (Fig. 3) confirm the data of Fig. $2(a)$ regarding energy output levels, but show that the peak of release of viable organisms was after 80 to IOo s sonication.

These experiments show the lethal effects of sonication. The maximum recovery of bacteria must be regarded as a balance between their rate of release from the flocs and the rate at which they are killed. It is unlikely that the death rate will be constant until complete disruption of the flocs has occurred, as the individual bacteria may be protected by their position within the floc. After prolonged sonication at the lowest intensity used, no appreciable decrease in the number of bacteria recovered was observed. This indicated either that 


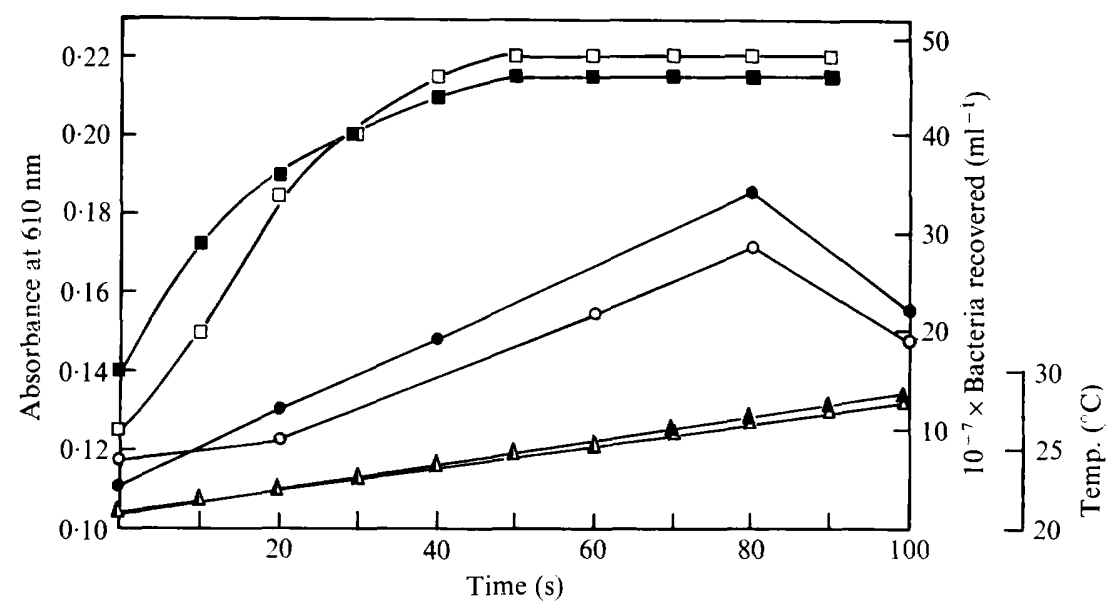

Fig. 5. Comparison of sonication of a sludge sample using two different sonicators : soniprobe model $7532 \mathrm{~A}$ setting 3 (closed symbols); model i 130 scale reading 3.6 (open symbols). Absorbance $(\square, \square)$, bacteria recovered $(\boldsymbol{O}, O)$ and temperature $(\boldsymbol{\Delta}, \Delta)$ were measured after increasing periods of sonication. Sludge was obtained from a laboratory activated sludge unit.

Table I. The recovery of bacteria from diluted sonicated mixed liquor obtained from six municipal treatment works on CGY, MP and TGEVA agars

Values are the mean of two independent determinations.

Treatment
works

A
B
C
D
E
F

$10^{-8} \times$ Bacteria recovered $\left(\mathrm{ml}^{-1}\right)$

$\begin{array}{ccc}\text { CGY agar } & \text { TGEVA agar } & \text { MP agar } \\ 12.4 & 9.6 & 3.2 \\ 5.3 & 5.6 & 3.0 \\ 3.5 & 1.4 & 0.35 \\ 2.15 & 0.56 & 0.75 \\ \text { I.2 } & 0.4 & 0.9 \\ \text { I. I5 } & 0.5 & \text { I.7 }\end{array}$

the release of cells from the flocs had ceased and there was no killing, or that the rate of release exactly compensated for the death rate; the former explanation seems to correlate with the physical measurements.

\section{Comparison of sludges}

After sonication using optimum power output, the viable bacteria in samples of diluted mixed liquor from Io activated sludge plants were counted. Samples taken at $20 \mathrm{~s}$ intervals were spread-plated on nutrient agar (Oxoid no. 3) and incubated for 7 days at $20^{\circ} \mathrm{C}$. The plate counts were expressed as a percentage of the maximum plate count for that sludge, for comparative purposes. The time of sonication for maximum recovery of viable organisms from the sludges varied between 40 and I00 s. Two typical patterns of recovery were observed (Fig. 4). In one, the graphs of viable cell count against sonication time showed a sharp peak; in the other, the graph was rounded and there was little decrease in viable count after the maximum had been reached. Hence it was not possible to define the precise requirements for achieving optimum results with different sludges, and it was concluded that until the characteristics of a sludge are assessed, a range of sonication times between I and 2 min should be used. 


\section{Standardization of instruments}

The criteria relating physical characteristics of sonicated sludge to the maximum release of recoverable bacteria, using temperature increase as a measure of energy input, made it possible to standardize one instrument against another by physical measurements only. Figure 5 relates measurements on the two Dawe soniprobes. Power setting 3 on model 7532A gave a power output of $30 \mathrm{~J} \mathrm{~s}^{-1}$, similar to the optimum value found using model I 130 . The two instruments were also comparable in tests of the rate and magnitude of viable bacterial release although model $7532 \mathrm{~A}$ gave slightly greater release.

\section{Comparison of recovery media}

Table I shows the number of organisms recovered per $\mathrm{ml}$ of diluted mixed liquor on CGY agar, TGEVA and MP agar, after sonication for $80 \mathrm{~s}$ under optimum conditions. The numbers of bacteria recovered for each plant varied, being dependent on mixed liquor suspended solids and viable content. Weddle \& Jenkins (I97I) have shown that the viable content is related to the net growth rate of the sludge.

The results presented here indicate that the best recovery medium may vary from one sludge to another. However, in our experience CGY agar has proved to be the most generally useful medium for the cultivation and isolation of activated sludge bacteria.

We thank the North West Water Authority, Severn-Trent Water Authority and Yorkshire Water Authority for the provision of facilities. The Science Research Council awarded CASE studentships, with additional support of Simon-Hartley Ltd, Stoke-on-Trent (for C.J.B.) and W.R.C., Stevenage Laboratory (for I.W.)'

\section{REFERENCES}

ALLEN, L. A. (1944). The bacteriology of activated sludge. Journal of Hygiene, Cambridge 43, 424-43I.

BANKS, C. J., DAVIES, M., WALKer, I. \& WARD, R. D. (1976). Biological and physical characterisation of activated sludge: a comparative experimental study at ten treatment plants. Water Pollution Control 75, 492-508.

KIFF, R. J. (1975). A study of the ecological factors influencing the efficiency of the activated sludge system for treating organic wastes. Ph.D. thesis, University of Aston.

LighthaRT, B. \& OGLesBY, R. T. (1969). Bacteriology of an activated sludge wastewater treatment plant a guide to methodology. Journal of the Water Pollution Control Federation 4r, 267-281.

Meynell, G. G. \& Meynell, E. (1965). Theory and Practice in Experimental Bacteriology, ist edn. London: Cambridge University Press.

Pike, E. B., CARrington, E. G. \& Ashburner, P. A. (1972). An evaluation of procedures for enumerating bacteria in activated sludge. Journal of Applied Bacteriology 35, 309-32I.

Prakasam, T. B. S. \& DonDERo, N. C. (1967a). Aerobic heterotrophic bacterial populations of sewage and activated sludge. I. Enumeration. Applied Microbiology 15, 46I-467.

Prakasam, T. B. S. \& Dondero, N. C. (1967 b). Aerobic heterotrophic bacterial populations of sewage and activated sludge. III. Adaptation in a synthetic waste. Applied Microbiology 15, I I 28 -I I 37.

UNZ, R. F. \& DAVIS, J. A. (1975). Microbiology of combined chemical-biological treatment. Journal of the Water Pollution Control Federation 47, I85-194.

WedDLE, C. L. \& JenKINS, D. (I97I). The viability and activity of activated sludge. Water Research 5, 62I640.

Williams, A. R., StafFord, D. A., CAlley, A. G. \& Hughes, D. E. (1970). Ultrasonic dispersal of activated sludge flocs. Journal of Applied Bacteriology 33, 656-663.

Williams, A. R., Forster, C. F. \& HUGHES, D. E. (I97I). Using an ultrasonic technique in enumeration of activated sludge bacteria. Effluent Water Treatment Journal Ir, 83-86. 